\title{
LOWER INSTANCE NATIONAL COURTS AND TRIBUNALS IN MEMBER STATES, AND THEIR JUDICIAL DIALOGUE WITH THE COURT OF JUSTICE OF THE EUROPEAN UNION
}

\author{
GRAHAM BUTLER*
}

\begin{abstract}
The vast majority of cases that are submitted to the Court of Justice of the European Union (the Court) through the preliminary reference procedure that is contained in Article 267 TFEU come from lower instance national courts and tribunals in EU Member States. As a result, it is not always appellate courts, or higher instance national courts and tribunals, such as courts of final appeal, which make orders for reference. Judicial dialogue between national courts and the Court through this Article 267 TFEU procedure is notable for its particular quality of it being open to receiving orders for reference, for an interpretation of EU law from national courts and tribunals - of any instance - from first instance, to final instance. But can this judicial dialogue between lower instance national courts and tribunals and the Court be impeded by national courts' more senior national Brethren, with appeals being allowed against orders for reference within national legal orders? The case law of the Court on such an issue bas been progressive, in that it developed slowly over time, and the Court, by 2021, becoming increasingly assertive. As will be analysed in this article, the Court's approach to the arising issue has clearly been an attempt to balance the interests of judicial dialogue on the one hand, and national rules on the other. Yet, with the Court's broader case law tightening the understanding of who constitutes the European judiciary, and ensuring that all national courts and tribunals remain independent from executive interference in EU Member States, the article commends recent developments, but makes the further plea for an affirmative judgment of the Court to not permit, as a matter of EU law, appeals against orders for reference made by lower instance national courts and tribunals in EU Member States, in the name of preserving judicial dialogue through the preliminary reference procedure.
\end{abstract}

\section{INTRODUCTION}

The importance of the preliminary reference procedure to the functioning of the EU legal order, and the effectiveness of EU law, is well-known. ${ }^{1}$ It has been described as everything from its indispensability, to being the 'crown in the jewel' in having a functioning EU legal

\footnotetext{
* Associate Professor of Law, Aarhus University, Denmark.

${ }^{1}$ See, inter alia, Anthony Arnull, 'The Past and Future of the Preliminary Rulings Procedure' in Mads Andenas and John A Usher (eds), The Treaty of Nice and Beyond: Enlargement and Constitutional Reform (Hart Publishing 2003); Xavier Groussot, 'Spirit Are You There? - Reinforced Judicial Dialogue and the Preliminary Ruling Procedure' (2008) 4 Europarättslig tidskrift 934; Clelia Lacchi, 'Multilevel Judicial Protection in the EU and Preliminary References' (2016) 53 Common Market Law Review 679; Koen Lenaerts, 'Form and Substance of the Preliminary Rulings Procedure' in Deirdre Curtin and Tom Heukels (eds), Institutional Dynamics of European Integration: Essays in Honour of Henry G. Schermers, Volume II (Martinus Nijhoff Publishers 1994); Allan Rosas, 'The Preliminary Rulings Procedure' in Dennis Patterson and Anna Södersten (eds), A Companion to European Union Law and International Law (John Wiley \& Sons, Inc 2016).
} 
order. But it only does so because judicial dialogue is with all national courts and tribunals, and not just those of higher instance. Article 267 TFEU, in theory and in practice, protects and preserves judicial dialogue for all national courts and tribunals. But to what extent do lower instance national courts and tribunals, to whom potential appeals against their actions may lie, have their judicial dialogue with the Court protected by that very same Court?

The overwhelming majority of the cases on the docket of the Court ${ }^{2}$ are those that are referred to it by national courts and tribunals in EU Member States through the preliminary reference procedure that is provided for in Article 267 TFEU. It constitutes the formal means of judicial dialogue in the EU. Why specific cases reach the Court through this procedure is something of a mystery, and each case through the procedure is subject to its own factual context. This said, the preliminary reference procedure makes a distinction between 'higher' and 'lower' instance national courts and tribunal, given the very language of Article 267 TFEU. There are a whole host of reasons for why a national court or tribunal of a Member State may refer, if they 'consider [...] that a decision on the question is necessary to enable it to give judgment'. ${ }^{3}$ This is in regard to lower instance national courts and tribunals. ${ }^{4}$ But this 'may' quickly turns into a 'shall, for higher instance national courts and tribunals, when the latter's ruling there can be no appeal from.

Article 267 TFEU provides for this judicial dialogue between national courts and tribunals and the Court, and it states,

The Court of Justice of the European Union shall have jurisdiction to give preliminary rulings concerning:

(a) the interpretation of the Treaties;

(b) the validity and interpretation of acts of the institutions, bodies, offices or agencies of the Union;

Where such a question is raised before any court or tribunal of a Member State, that court or tribunal may, if it considers that a decision on the question is necessary to enable it to give judgment, request the Court to give a ruling thereon.

Where any such question is raised in a case pending before a court or tribunal of a Member State against whose decisions there is no judicial remedy under national law, that court or tribunal shall bring the matter before the Court.

If such a question is raised in a case pending before a court or tribunal of a Member State with regard to a person in custody, the Court of Justice of the European Union shall act with the minimum of delay.

Whilst facilitating judicial dialogue to enable the Court 'to give a ruling', there are many unanswered questions regarding Article 267 TFEU: what is a court of a Member State? What is a tribunal of a Member State? What does 'of a Member State' mean? Are national courts and tribunals obligated to make a reference for a preliminary ruling? What is a court or

\footnotetext{
${ }^{2}$ In this article, 'the Court' refers to the Court of Justice within the institution of the Court of Justice of the European Union.

${ }^{3}$ Treaty on the Functioning of the European Union (TFEU) [2016] OJ C202/47, art 267(2). It is a different matter, however, for national courts and tribunals 'against whose decisions there is no judicial remedy under national law, that [such] court or tribunal shall bring the matter before the Court', as per Article 267(3) TFEU.

${ }^{4}$ In this article, 'lower instance national courts and tribunals' is understood as bodies to which are not those considered as those falling into Article 267(3) TFEU.
} 
tribunal 'against whose decisions there is no judicial remedy'? What questions can be referring under the procedure? At what stage of a national procedure can questions be referred to the Court? What is to be contained in the reference made by a national court or tribunal?

Guidance of how to answer such (and further) questions under Article 267 TFEU has been considered in the case law. ${ }^{5}$ In every case, the determining factors that motivate a national court or tribunal to make an order for reference under Article 267 TFEU may differ, but the very decision of a national court or tribunal to make a reference is not always welcome by the parties before national courts and tribunals. Therefore, the natural question arises: can a decision of a national court or tribunal of lower instance, who makes an order for reference under Article 267 TFEU to the Court, be appealed within the national legal order to a higher instance national court? Furthermore, if such decisions are appealed, what is the scope of the powers of the higher instance national courts and tribunals? And does EU law limit the effects of appeals made to higher instance national courts and tribunals against orders for reference made by lower instance national courts and tribunals?

The Court's jurisprudence on how to deal with the different instances in Member States, and the status of the preliminary reference procedure, as will be demonstrated in this article, ${ }^{6}$ has varied over time. Whilst the current case-law veers on the side of preventing higher instance national courts and tribunals from interfering in lower instance national courts and tribunals, the case-law has not fully dispelled the underlying problem of the potential for lower instance national courts and tribunal's decisions to refer being subject to a national appeal process, and the wider chilling-effect it could have. ${ }^{7}$ This article makes the case that national courts and tribunals, of lower instance - that may make a preliminary reference - should retain as broad a discretion as conceivably possible to make orders for reference under Article 267 TFEU, thus having unfettered discretion in engaging in judicial dialogue with the Court. In doing so, this position promotes even wider use of EU law, ensuring that it remains effective, so that actors do not have to engage in long, protracted legal disputes in national courts and tribunal, in the mere hope that higher instance, or final instance national courts and tribunals, make orders for reference.

This article is structured as follows. Section 2 reflects on the history of the issue of judicial dialogue between lower instance national courts and tribunals with the Court, and how appeals against orders for reference were handled. As demonstrated, whilst the Court initially waivered on how to handle the issue of appeals brought against decisions of lower instance national courts and tribunals making orders for reference, it ultimately settled on a compromise between the effectiveness of EU law, and making allowances for national rules.

\footnotetext{
${ }^{5}$ For the most comprehensive, and authoritative single source of analysis on many of the issues arising under Article 267 TFEU, see, Morten Broberg and Niels Fenger, Broberg and Fenger on Preliminary References to the European Court of Justice (3rd edn, OUP 2021)., and previous editions (1st edn in 2010, and 2nd edn in 2014). ${ }^{6}$ Elsewhere, previously, in the context of the Schrems II case, the Court passed on an opportunity presented to it on curtailing appeals. See, Graham Butler and John Cotter, 'Just Say No! Appeals Against Orders for a Preliminary Reference' (2020) 26 European Public Law 615.

${ }^{7}$ For earlier consideration of the arising issues as Community law, later Union law, once stood, see, David O'Keeffe, 'Appeals Against an Order to Refer under Article 177 of the EEC Treaty' (1984) 9 European Law Review 87. Subsequent writing has also analysed the case-law as it has developed. See, Michal Bobek, 'Cartesio: Appeals against an Order to Refer under Article 234(2) EC Treaty Revisited' (2010) 29 Civil Justice Quarterly 307; Morten Broberg and Niels Fenger, 'Preliminary References as a Right - but for Whom? The Extent to Which Preliminary Reference Decisions Can Be Subject to Appeal' (2011) 36 European Law Review 276.
} 
Firstly, it settled on proceeding with cases that were validly submitted to the Court through the preliminary reference procedure, notwithstanding a national appeals procedure; whilst secondly, it did not state that appeals being brought against decisions to make orders were contrary to Article 267 TFEU. This, is categorised as the 'old case law'.

Next, section 3 moves on to analyse what is called what is branded the 'new case law'. Here, two cases from the Court come into sharp focus, given they affirmatively moved on from prior jurisprudence. Firstly, in Cartesio, ${ }^{8}$ the Court decided to try and limit the effects of any decisions of higher instance national courts and tribunals against decisions of lower instance national courts and tribunals that involved making an order for reference through Article 267 TFEU. Whilst the Cartesio judgment was thus a firmer strengthening of judicial dialogue between lower instance national courts and tribunals and the Court, that the Court had taken in the 'old' case law, the Court however, still, did not rule out the possibility of appeals being made in national legal systems against decisions regarding orders for reference. Secondly thereafter, in IS, the Court built on Cartesio, by going even further. This time, the Court appeared to take a stronger position than it ever had. Here, it stated that lower instance national courts and tribunal ought to invoke the primacy of EU law, specifically the primacy of Article 267 TFEU against decisions of higher instance national courts and tribunals, to ensure that its judicial dialogue between lower instance national courts and tribunals and the Court is preserved. However, again, still, the Court did not rule out the possibility of appeals being made in national legal systems against decisions regarding orders for reference.

Penultimately, section 4 considers the case for clarity, in which, in the view of this author, the Court ought to go even further than it has in Cartesio and IS, and affirmatively rule out the mere possibility of appeals, whilst lower instance national courts and tribunals are engaged in judicial dialogue with the Court through the preliminary reference procedure. Conclusively, section 5 rounds out the argument, by putting the issue in a broader context.

\section{APPEALS AGAINST DECISION TO REFER, AND THE OLD CASE LAW}

\subsection{THE ORIGINAL POSITION}

Early in the Court's jurisprudence, it decided that if an appeal against an order for reference by a lower instance national court or tribunal was brought to a higher instance national court or tribunal, the pending case on the docket of the Court would continue to proceed. Whilst the Court was operational since 1952 hearing a range of direct actions, it was not until 1961 when the Court received its first ever case through the preliminary reference procedure, then located in Article 177 EEC (now Article 267 TFEU) in De Geus en Uitdenbogerd $v$ Bosch and Others (De Geus v Bosch). ${ }^{9}$ The case had been submitted to the Court by a lower instance national court or tribunal, the Gerechtshof's-Gravenhage (Court of Appeal, The Hague). But within the Dutch judicial system, the decision of the Court of Appeal to refer questions to the Court was appealed to a higher instance national court or tribunal.

\footnotetext{
${ }^{8}$ Case C-210/06 CARTESIO Oktató és Sqolgáltató bt (CARTESIO) ECLI:EU:C:2008:723.

${ }^{9}$ Case 13/61 De Geus en Uitdenbogerd v Bosch and Others (De Geus v Bosch) ECLI:EU:C:1962:11.
} 
Going first in adjudicating on the arising issue, Advocate General (AG) Lagrange rejected the view that just because a decision of a lower instance national court to make an order for reference had been appealed, that this would result in the Court having to suspend proceedings before it, until such appeal proceedings at national level had ended. ${ }^{10}$ Using its own reasoning, the Court in essence agreed with AG Lagrange. The Court stated,

Just as the Treaty does not prevent the national [higher instance national court or tribunal] from taking cogni[s]ance of the petition but leaves the determination of its admissibility to the national law and the decision of the national judge, [...] the Treaty makes the jurisdiction of this Court dependent solely on the existence of a request for a preliminary ruling within the meaning of Article [267 TFEU]. And it does so without requiring this Court to discover whether the decision of the national judge has acquired the force of res judicata under the national law. ${ }^{11}$

De Geus v Bosch was therefore a strong endorsement of the rights of lower instance national courts and tribunals within the EU legal order, and ensuring they could have judicial dialogue with the Court. Evidently therefrom, whilst the case was on the docket of the Court, referred to it from a national court or tribunal - of whatever instance - the case remained live.

Whilst the judgment in De Geus v Bosch was not directly criticising the decision of one of the parties in the national proceedings to appeal the decision to refer, nor preventing the higher instance national court or tribunal from acting in any way, the Court's position was reasonably clear for its time in the early years of the EU legal order: whilst a case was before it through the preliminary reference procedure, it would proceed in answering the questions put to it. The Court did not, consequently, delve into the intricacies of the underlying national legal system, and how appeals against such decision to make an order for reference, in the 'may' refer scenario envisaged by Article 267 TFEU, would be handled by higher instance national courts and tribunals.

That said, whilst De Geusv Bosch was a favourable judgment for lower instance national courts and tribunals, it did not appear to rule out the possibility of having appeals brought against the decisions of lower instance national courts and tribunals to make orders for reference. In that sense, the judgment in De Geus v Bosch paid due deference to national rules. Instead, the Court merely confirmed itself to the specificities of the case at hand - an act of judicial minimalism - and continue with the case on its docket, given it is duly seized of the matter by the referring national court or tribunal.

\subsection{THE SECOND POSITION}

Subsequently, the Court changed its mind on the position it took in De Geus v Bosch, at least initially. It then held that if an appeal was brought to a higher instance national court or tribunal against a decision of a lower instance national court or tribunal to make an order for reference, the pending case on the docket of the Court would be suspended. Thus, the position of the Court in De Geus v Bosch was short-lived, at least initially.

\footnotetext{
${ }^{10}$ For his full reasoning, see, Opinion of Advocate General Lagrange, Case 13/61 De Geus v Bosch ECLI:EU:C:1962:3, page 59.

${ }^{11}$ De Geus v Bosch (n 9), page 50 (emphasis added).
} 
On the next occasion in which the Court was faced with the same scenario, this time in Chanel v Cepeha, which was a referral from the Arrondissementsrechtbank Rotterdam (District Court of Rotterdam), the Court had a change of heart over the effect of the case on its docket whilst an appeal against the decision of the lower instance national court or tribunal's to make an order for reference was being heard. ${ }^{12}$ Moreover, it is a case where the influence of the AG might be seen to be particularly prominent. ${ }^{13} \mathrm{AG}$ Roemer in Chanel $v$ Cepeha took a different view to that of his former colleague - AG Lagrange - and the judgment of the Court in De Geus v Bosch. For AG Roemer, instead, the appeal against the decision of the District Court of Rotterdam to the Court of Appeal in The Netherlands ${ }^{14}$ ought, in fact, to result in the proceedings before the Court not proceeding, and the case be stayed on the Court's docket. AG Roemer stated,

I propose that the Court issue an order declaring that for the moment it cannot give a ruling on the questions submitted to it; it may only do so when the [higher instance national court] has given judgment on the appeal brought against the decision to make the reference. ${ }^{15}$

For him, the Court 'cannot simply ignore the situation', ${ }^{16}$ and, the 'necessary result must be a stay of proceedings on the reference until a decision has been given at the national level with regard to whether the interpretation requested is of importance in deciding the case or not'. ${ }^{17}$

Remarkably, the Court in Chanel $v$ Cepeha agreed, issuing a very brief order, stating, that '[i] udgment in the present case is suspended pending notification to the Court that the appeal has been decided'. ${ }^{18}$ No reasons were given by the Court for its position, other than that it was deciding so '[i]n the circumstances of the case', and no further reasoning was provided for why it had turned its back on its decision in De Geus v Bosch so swiftly.

Just over a year later, the Court delivered a second order in Chanel $v$ Cepeha. Following a communication from the referring lower instance national court or tribunal - the District Court of Amsterdam - that the higher instance national court or tribunal had amended the judgment of the lower instance national court or tribunal. Therefore, the referring court stated that 'the reference for interpretation has lost its purpose'. ${ }^{19}$ The Court, accordingly, removed the case from its docket. No further explanation was given for the Court's action, or any other reasoning in its first order. Whilst problematic for its lack of reasoning, it was

\footnotetext{
${ }^{12}$ Case 31/68 SA Chanelv Cepeha Handelsmaatschappij NV (Chanelv Cepeha) ECLI:EU:C:1970:52, page 405.

${ }^{13}$ On the role played by AGs at the Court, see, Graham Butler and Adam Lazowski (eds), Shaping EU Law the British Way: UK Advocates General at the Court of Justice of the European Union (Hart Publishing 2022).

${ }^{14}$ By coincidence, the higher instance national court in Chanel v Cepeha, was the Court of Appeal in The

Hague, was the same national court in the De Geus v Bosch case, whose own decision was subject to an appeal to an even higher instance national court.

${ }^{15}$ Opinion of Advocate General Roemer, Case 31/68 SA Chanelv Cepeha Handelsmaatschappij NV, ECLI:EU:C:1969:18, page 412.

16 ibid, page 409.

17 ibid.

18 Order of the Court in Case 31/68 SA Chanel v Cepeha Handelsmaatschappij NV ECLI:EU:C:1969:21.

${ }^{19}$ Chanel v Cepeha (n 12), page 405.
} 
particularly striking that no explanation was offered at all given this was an affirmative Uturn on prior case law. ${ }^{20}$

\subsection{A RETURN TO THE ORIGINAL POSITION}

Notwithstanding the fact that the Court had already changed its mind without explanation, its change of mind in Chanel $v$ Cepeha was not, in fact, long lasting. Rather, in BRT v SABAM thereafter, the Court went back to its prior position that it had in De Geus v Bosch.

In $B R T$ v $S A B A M$, a referral to the Court under Article 267 TFEU from the Tribunal of First Instance in Brussels (Tribunal de première instance de Bruxelles or Rechtbank van eerste aanleg te Brussel), the defendant notified the Court that it had appealed the decision of the national court in which it made the order for reference. The appeal was brought to a higher instance national court or tribunal in Belgium, and accordingly, the defendant pleaded that the Court should suspend the proceedings, whilst national appeal proceedings were ongoing. In effect, the defendant was seeking an order of the Court, akin to what the Court had done in Chanel $v$ Cepeha, pending the outcome of the appeal at national level.

The Court was informed by the referring lower instance national court or tribunal, after the submissions of the defendant, with some hesitation about its position, that it 'does not wish [that] the Court...suspend the examination' of the questions referred, in turn, effectively, asking the Court to take the approach that it had initially taken in De Geus v Bosch. In $B R T v S A B A M$ therefore, AG Mayras therefore had a task on his hand: state the Court follow its revised Chanel $v$ Cepeha position, unexplained as it was; or instead revert back to its initial position in De Geus v Bosch.

AG Mayras had the courage to recommend the Court revert to its original position of De Geus $v$ Bosch. For him, avoiding national procedural questions was of particular importance, noting that if the Court were to consider matters that were before higher instance national courts and tribunals, accounting for technical matters of national court, the Court would be 'exceed[ing] jurisdiction and encroach [ing] upon that of the [national] courts, since [the Court would] be forced to appraise the effects of the appeal against the order for reference in accordance with the rules of the national law'. ${ }^{21}$ He continued,

Article [267 TFEU] establishes direct cooperation between the Court of Justice and the national courts of the Member States which can make use of the power to refer to it, for preliminary rulings, any question of interpretation of Community law which they consider necessary for the solution of disputes brought before them. ${ }^{22}$

Thus, for AG Mayras, not only was a division of powers between national courts and tribunal and the Court important, but also the importance of judicial dialogue between all national

\footnotetext{
${ }^{20}$ For analysis on U-turns, see, Mirka Kuisma, Confronting Realities with the Legal Rule: On Why and How the European Court of Justice Changes Its Mind (PhD dissertation, University of Turku 2021); David T Keeling, "The Rehabilitation of Trade Marks, the Demise of the Doctrine of Common Origin, and the Overruling of Prior Case Law: Opinion of Advocate General Jacobs in HAG II' in Graham Butler and Adam Lazowski (eds), Shaping EU Law the British Way: UK Advocates General at the Court of Justice of the European Union (Hart Publishing 2022).

${ }^{21}$ Opinion of Advocate General Mayras, Case 127/73 Belgische Radio en Televisie and société belge des auteurs, compositeurs et éditeurs v SV SABAM and NV Fonior (BRT v SABAM) ECLI:EU:C:1974:11, page 69. 22 ibid.
} 
and courts and tribunals and the Court under Article 267 TFEU. His convincing argument held sway in the Court. In its judgment, the Court disavowed Chanel v Cepeha, but without stating so, nor stating that it was to return to its De Geus $v$ Bosch position. Instead, it simply stated that the case 'continues as long as the request of the national court has neither been withdrawn nor become devoid of object', ${ }^{23}$ and that 'as the preliminary questions of the [national court] have been duly referred to the Court[,] the latter is bound to give a reply'. ${ }^{24}$

De Geus v Bosch and BRT v SABAM were therefore to be seen as the affirmative position of the Court on the question on the effect of appeals made in national legal orders, and the effect they had on proceedings before the Court by the lower instance national court or tribunal who made orders for reference. However, given that BRT $v S A B A M$ was a reversion to the Court's original position, it would take subsequent jurisprudence to test whether the Court had settled on this position, or whether it would again change its mind, accounting again for the complete absence of reasoning of its decision in Chanel $v$ Cepeha.

Much later in Rheimmüblen-Düsseldorf I, a referral from the Bundesfinanzhof (Federal Fiscal Court) in Germany, the referring national court or tribunal asked a very pointed question to the Court on the intricacies of the preliminary reference procedure then contained in Article 177 EEC (now Article 267 TFEU). It asked,

[W] hether the second paragraph of Article 177 gives "to a court or tribunal against whose decisions there is a judicial remedy under national law a completely unfettered right to refer questions to the Court of Justice [or ...]

$[\mathrm{D}]$ oes it leave unaffected rules of domestic law to the contrary whereby a court is bound on points of law by the judgments of the courts superior to it? ${ }^{25}$

The pointedness of the case most likely lay because of the inconsistent case law that had come out of the Court on these issues, in which a lower instance national court or tribunal the Hessisches Finanggericht (Fiscal Court of Hesse), and a higher instance national court or tribunal - the Bundesfinan₹hof, were unsure of where the law stood, and the effect of orders for reference on the docket of the Court, which still had proceedings in national courts and tribunals. In this specific instance, the lower instance national court had itself made its own order for reference to the Court in Rheinmüblen-Düsseldorf $I I,{ }^{26}$ which was pending simultaneously.

The two Rheinmüblen-Düsseldorf cases thus offered the Court to clarify matters, and add more insight in the role of lower instance national courts and tribunals and the preliminary reference procedure. In a joined Opinion for both cases, AG Warner concurred with the Court's original position, ${ }^{27}$ that higher instance national courts and tribunals, and the national

\footnotetext{
${ }^{23}$ Case 127/73 BRT v SABAM ECLI:EU:C:1974:6 para 9.

24 ibid para 24.

${ }_{25}$ Case 166/73 Rheinmüblen-Düsseldorf v Einfuhr-und Vorratsstelle für Getreide und Futtermittel (RheinmüblenDüsseldorf I) ECLI:EU:C:1974:3.

${ }^{26}$ Case 146/73, Rheinmüblen-Düsseldorf v Einfuhr- und Vorratsstelle für Getreide und Futtermittel (RheinmüblenDüsseldorf II) ECLI:EU:C:1974:12. Despite this case being lodged by the lower instance national court first (Case 146/73), compared to that of the higher instance national court second (Case 166/73), the case lodged first was adjudicated upon later than the case lodged second, hence the case lodge first is known as Rheinmüblen-Düsseldorf II, and the case lodged second is known as Rheinmüblen-Düsseldorf I.

27 And also, therefore, the Opinion of AG Lagrange in De Geus v Bosch (n 10), and AG Mayras in BRT v $S A B A M($ n 21).
} 
laws and rules of Member States, could not interfere in the judicial dialogue between lower instance national courts and tribunals and the Court. For him, there were three principal reasons for his position,

First, and most obviously, it involves empowering the Member States to qualify by national legislation the terms of the Treaty.

Secondly it opens the way for the Treaty to apply differently in different Member States. One Member State might circumscribe the discretion of its lower Courts to refer questions to this Court more tightly than another. This, clearly, could injure both the uniform application of Community law and its balanced development.

Thirdly it means that, in deciding upon the admissibility of particular references, this Court must be faced with an impossible choice. It must either embark upon the interpretation and application of provisions of national law, including procedural ones - which is not its role — or it must ignore those provisions and thus allow to subsist a situation in which a reference may be admissible in Community law but inadmissible in national law. ${ }^{28}$

The strong position of AG Warner meant the Court was almost compelled to respond with an equally forceful position on the nature and scope of the preliminary reference procedure, and its dialogue that it enjoyed with lower instance national courts and tribunals. This was in particular because AG Warner had grilled the Court in his Opinion, noting the Court's position had been inconsistent, or worse, not sufficiently clear. ${ }^{29}$

The Court did not disappoint for the time, at least in Rheinmüblen-Düsseldorf I. There, it stated that 'every national court or tribunal without distinction to refer a case to the Court for a preliminary ruling when it considers that a decision on the question is necessary to enable it to give judgment', ${ }^{30}$ and that,

[...] national courts have the widest discretion in referring matters to the Court of Justice [... and] that a rule of national law whereby a court is bound on points of law by the rulings of a [higher instance national] court cannot deprive the [lower instance national] courts of their power to refer to the Court questions of interpretation of Community law involving such rulings. ${ }^{31}$

The Court further went out of its way to offer consequentialist logic on what would happen if the preliminary reference procedure was undermined by higher instance national courts and tribunals. The Court thus opined,

If [lower instance national] courts were bound [by higher instance national courts] without being able to refer matters to the Court, the jurisdiction of the latter to give

\footnotetext{
28 Opinion of Advocate General Warner, Case 146/73 Rheinmühlen-Düsseldorf II and Case 166/73 RheinmüblenDüsseldorf I ECLI:EU:C:1973:162.

${ }^{29}$ On the role that UK Advocates General, like AG Warner, made to EU law whilst they were within the Court until 2020, see, Butler and Lazowski (n 13).

30 Rheinmüblen Düsseldorf I (n 25) para 2.

31 ibid para 4 (emphasis added).
} 
preliminary rulings and the application of Community law at all levels of the judicial systems of the Member States would be compromised. ${ }^{32}$

In other words, lower instance national courts and tribunals retained rights under Article 267 TFEU that no higher instance national courts and tribunal could take away. This was not withstanding the fact that the Court did not rule out the possibility for appeals to be brought against decisions of lower instance national courts and tribunals to make orders for reference.

By contrast, in Rheinmüblen-Düsseldorf II, less convincingly, whilst the Court did not say that orders for preliminary references from lower instance national courts could not be the subject of an appeal, it did point out that regardless of an order being appealed, the Court would, '[n] evertheless, in the interests of clarity and legal certainty [...] abide by the decision to refer, which must have its full effect so long as it has not been revoked'. ${ }^{33}$ However, it went on to say that, 'Article [267 TFEU] does not preclude a decision of such a court referring a question to this Court for a preliminary ruling from remaining subject to the remedies normally available under national law,. ${ }^{34}$ Whilst Rheinmüblen-Düsseldorf II was nonetheless favourable towards lower instance national courts and tribunals like in Rheinmüblen-Düsseldorf $I$, in principle, it paved the way for caveats to be made.

Thus, De Geus v Bosch, BRT v SABAM, Rheinmüblen-Düsseldorf I, and RheinmüblenDüsseldorf II was in the direction of offering protection to lower instance national courts and tribunals from higher instance national courts and tribunals (and perhaps, even the national rules in Member States), in ensuring their dialogue with the Court through Article 267 TFEU. Collectively, whilst all being building blocks in their own right on the nature of the preliminary reference procedure, on the issue of appeals, these cases can be considered the 'old case law', given that, whilst still being valid, the Court has later developed its case law quite considerably, and do not reflect current thinking and practice.

\section{APPEALS AGAINST DECISIONS TO REFER, AND THE NEW CASE LAW}

Whilst these earlier judgments became settled law for some time, there was clearly caveats in the Court's jurisprudence that paved the way for potential exploitation if appeals were brought against orders for reference to higher instance national courts and tribunals. For example, what if national law allowed for higher instance national courts and tribunals to overturn such decisions of lower instance national courts and tribunals? Or amend the text of the order for reference that the lower instance national court or tribunal had submitted to the Court? The perceived position, given this 'old case law', was that the Court would not necessarily get involved in national procedural matters, as long as it was the referring national court or tribunal itself that was engaged in the judicial dialogue.

But this position was by no means certain. For example, academic literature had different perspectives. For example, one view was that 'no rule of national law can fetter the

\footnotetext{
32 Rheinmühlen Düsseldorf I (n 25) para 4.

33 Rheinmüblen-Düsseldorf II (n 26) para 3.

34 ibid.
} 
discretion of a lower court to make a reference'. ${ }^{35}$ Elsewhere was the position that appeals of references made by lower instance national courts and tribunal were allowed. ${ }^{36}$ Such positions was justified at the time, though it might have been plausibly suggested that the views of such authors filled in the blanks as regards the lack of further clarity from the Court.

\subsection{CONSTRAINING THE RELEVANCE OF HIGHER INSTANCE NATIONAL COURTS AND TRIBUNALS}

Much time past until the Court was faced with the conundrum in Cartesio, which marked a new departure for what became the 'new case law'. Here, the Szegedi Itélótábla (Regional Court of Appeal in Szeged) asked the Court, like in Rheinmüblen-Düsseldorf I, a rather pointed question. It asked, inter alia,

Does a national measure which, in accordance with national law, confers a right to bring an appeal against an order for a preliminary reference, limit the power of the [lower instance national] courts to refer questions for a preliminary ruling or could it limit that power - derived directly from Article [267 TFEU] - if, in appeal proceedings the [higher instance national court] may amend the order, render the request for a preliminary ruling inoperative and order the court which issued the order for reference to resume the national proceedings which had been suspended? $?^{37}$

In essence, the question as to whether it was compatible with EU law for the national law of a Member State to allow a decision of a lower instance national court or tribunal, to make an order for reference, to be appealed to a higher instance national court or tribunal, which could either: amend the reference; render the reference inoperative; or force the lower instance national court or tribunal to resume proceedings, notwithstanding the reference to the Court.

Faced with such questions in a straightforward manner, the Court in Cartesio was bolder than it had ever been. Instead of being deferent to potential appeals that may lie within national legal orders, as it had in the 'old case law', against decisions of lower instance national courts and tribunals to make to make orders references, the Court qualified the scope of national procedural rules that could exist in the area. Whilst restating its position from the 'old case law', the Court then added,

Nevertheless, the outcome of such an appeal cannot limit the jurisdiction conferred by Article [267 TFEU] on that [referring] court to make a reference to the Court if it considers that a case pending before it raises questions on the interpretation of provisions of [Union] law necessitating a ruling by the Court. ${ }^{38}$

\footnotetext{
${ }^{35}$ Francis G Jacobs and Andrew Durand, References to the European Court: Practice and Procedure (Butterworths 1975) 171.

${ }^{36}$ Finbarr Murphy, 'Campus Oil Ltd., Estuary Fuel Ltd., McMullan Bros. Ltd, Ola Teoranta, P.M.P.A. Oil Company Ltd., Tedcastle McCormick and Company Ltd. v. The Minister for Industry and Energy, Ireland, The Attorney General and The Irish National Petroleum Corporation Ltd. (1982-1983) J.I.S.E.L. 43; (1984) 1 C.M.L.R. 479.' (1984) 21 Common Market Law Review 741, 749.

${ }^{37}$ Case C-210/06 CARTESIO Oktató és Szolgáltató bt (Cartesio) ECLI:EU:C:2008:723, para 40.

38 CARTESIO (n 37) para 93 (emphasis added).
} 
It continued that 'the assessment of the relevance and necessity of the question referred for a preliminary ruling is, in principle, the responsibility of the referring court alone' ${ }^{39}$

Therefore, the Court's position in Cartesio was that decisions of lower instance national courts and tribunals to make orders for reference under Article 267 TFEU could not be called into questions by national law, or the practice of higher instance national courts and tribunals to vary the reference, stop the reference, or to order resumption of the proceedings of the lower instance national court.

The Court's judgment in Cartesio was quite far-reaching, ${ }^{40}$ in that Article 267 TFEU was to be interpreted in a manner that any national court or tribunal could make an order for reference, which could not be called into question by the application of national procedural rules. On the extreme end of Cartesio, it can be read as an attempt to level the hierarchy of the national courts and tribunals in EU Member States in their judicial dialogue with the Court. Though the Court, like its historic case law, did not actually rule out the possibility of appeals, notwithstanding the effects that Cartesio would have on such appeals.

This said, the Court did not go as far as AG Poiares Maduro in Cartesio, who had a bolder, more daring proposition to eliminate the very potential for higher instance national courts and tribunals to still have an upper hand, and interfere with the judicial dialogue of lower instance national courts and tribunals and the Court. Instead, for him, the power to make an order for reference derived from the EU Treaties themselves through Article 267 TFEU. As he put it,

The Treaty did not intend that such a dialogue [between lower instance national courts and tribunal and the Court] should be filtered by any other national courts, no matter what the judicial hierarchy in a State may be. ${ }^{41}$

In line with ordinary consequential line of reasoning, and clearly of the same spirit as that of the Opinion of AG Warner in the Rheinmüblen Düsseldorf cases, AG Poiares Maduro feared that the preliminary reference procedure would end up only in the hands of higher instance national courts and tribunals, if appeals in national legal orders were possible. As he stated in Cartesio,

[1] $\mathrm{t}$ could happen that, by virtue of a national rule or practice, orders for reference by lower courts would systematically become subject to appeal, giving rise to a situation in which - at least de facto - national law allowed only courts of last instance to refer questions for a preliminary ruling. The risk of treating such question as a question of national procedural law and not Community law is highlighted by the present case [Cartesio] in which the national law permits a separate appeal against a decision to make a reference for a preliminary ruling. It would be tantamount to allowing national procedural law to alter the conditions set out in Article [267 TFEU] for a reference to the Court of Justice.

\footnotetext{
39 ibid para 96.

${ }^{40}$ For a reassertion of Cartesio, see, Case C-470/12 Pohotovost's. r. o. v Miroslav Vašuta ECLI:EU:C:2014:101, paras 25-35.

${ }_{41}$ Opinion of Advocate General Poiares Maduro, Case C-210/06 CARTESIO ECLI:EU:C:2008:294, para 19.
} 
In other words, he favoured a more absolutist approach, whereby appeals brought against decisions of lower instance national courts and tribunals to make orders for reference would not be appealable at all.

Notwithstanding the fact that the Court's judgment in Cartesio did not rule out appeals, the judgment was nonetheless reasonable, and a clear development of the law of Article 267 TFEU. It came closest the Court had to date in establishing an affirmative right of lower instance national courts and tribunals to have judicial dialogue with the Court. And it did gut, to some extent, the effectiveness of the appeal procedure at national level, given it would have little effect on the judicial dialogue between the referring lower instance national court or tribunal and the Court. The leading authority on the preliminary reference procedure goes further, however, reading that the Cartesio judgment effectively meant that decision of the higher instance national courts and tribunals, on appeal, 'can merely be an advisory opinion for the lower court'. ${ }^{42}$

Outstanding problems have remained, given the Court has not ruled out appeals themselves. Given the case law did not forbid appeals, there would be the continued potential for an appeal procedure, against decisions of lower instance national courts and tribunals to make orders for reference to delay, frustrate, and assert pressure on lower instance national courts and tribunals in their judicial dialogue with the Court. Moreover, the case law to date did not preclude higher instance national courts and tribunals from taking control of the main proceedings for itself on appeal, thereby obviating the need for any order for reference made by a lower instance national court or tribunal. Furthermore, what would happen if a higher instance national court or tribunal stated that the premise upon which the lower instance national court and tribunal had made a preliminary reference on the basis of making an error regarding findings of fact in which the reference was made. ${ }^{43}$ Cartesio was far from being the end of the story.

\subsection{THE INVOCATION OF PRIMACY, BUT CONTINUED REFUSAL TO ELIMINATE THE POSSIBILITY OF APPEALS}

The relevance of appeals brought decisions of lower instance national courts and tribunals to refer to the Court raised its head again post-Cartesio, in the IS case. This time, the referring lower instance national court or tribunal brought explicit concerns to the Court, through the preliminary reference procedure, that if appeals were allowed against such decisions to make orders for reference by lower instance referring courts and tribunals, it would have a deterrent effect from even contemplating making referrals under Article 267 TFEU. ${ }^{44}$ This was, in essence, the concerns of AGs Warner and Poiares Maduro, which were never fully met by the Court, notwithstanding its narrowing of the relevance of appeals brought.

In its IS judgment in 2021, the Court maintained that appeals of decisions of lower instance national courts and tribunals to make orders for reference were possible, or in the language of the Court, 'Article 267 TFEU does not preclude an order for reference from

\footnotetext{
42 Broberg and Fenger (n 5) 296.

43 As seen in Butler and Cotter (n 6).

${ }^{44}$ Case C-564/19 IS (Illégalité de l'ordonnance de renvoi) ECLI:EU:C:2021:949, para 42.
} 
being subject to a judicial remedy under national court ${ }^{45}$ and applied the three elements of the Cartesio case.

However, the rather than just state - as it did - that appeals against such decisions were allowed, the Court nonetheless seized the opportunity to clarify further matters, and sought to build on Cartesio by putting lower instance national courts and tribunals. The Court, for the first time, engaged with the wider effects of the possibility of such appeals, similar to the concerns of its AGs in prior cases. The Court stated such that appeals being pursued in higher instance national courts and tribunals, against decisions of lower instance national courts and tribunals in making orders for reference,

is likely to prompt the [national] courts to refrain from referring questions for a preliminary ruling to the Court, in order to preclude their requests for a preliminary ruling from being challenged by one of the parties on the basis of the [higher instance national court or tribunal] decision or from being the subject of an appeal in the interests of the law. ${ }^{46}$

From there, the Court recalled its exertions from Van Gend en Loos, and further noted, in a similar vein to AG Poiares Maduro in Cartesio, of the effects of such appeals, in that,

Limitations on the exercise by national courts of the jurisdiction conferred on them by Article 267 TFEU would have the effect of restricting the effective judicial protection of the rights which individuals derive from EU law. ${ }^{47}$

Therefore, rather, that stating that appeals against referrals were not possible, the Court went for a different route, which was to empower lower instance national courts and tribunals visà-vis their senior Brethren in the national legal orders, through the invocation of primacy of EU law over national law, and decisions of higher instance national courts and tribunals. For the Court,

the principle of the primacy of EU law requires a lower court to disregard a decision of the supreme court of the Member State concerned if it considers that the latter is prejudicial to the prerogatives granted to that lower court by Article 267 TFEU. ${ }^{48}$

This was the key distinction of IS from its prior Cartesio judgment, notwithstanding they both belonged to the 'new case law'. In $I S$, it would thus appear that the Court finally came to the view that the caveats to its existing case law were beginning to be exploited. Furthermore, the Court concerned itself with the wider effects of such appeals against decisions to make orders for reference, beyond the case at hand, and more willing to look at the wider factors that lead a lower instance national court or tribunal to make an order for reference.

The Court's IS judgment in effect, over and above prior case law, demands that lower instance national courts and tribunals disregard any practice in a national judicial system that prejudices their rights to make a preliminary reference under Article 267 TFEU, and demands that lower instance national courts and tribunals disregard decisions of higher

\footnotetext{
${ }^{45}$ IS (n 44) para 72.

46 ibid para 75 .

47 ibid para 76.

48 ibid para 81.
} 
instance national courts and tribunals that interfere in their judicial dialogue with the Court. This was a deeper cut into national procedures, and certainly envisages the Court taking a more assertive approach towards appeals brought against decisions of lower instance national courts and tribunal to make orders for reference into the future.

\section{APPEALS AGAINST DECISIONS TO REFER, AND THE NEED FOR CLARITY}

Appeal against decisions of lower instance national courts or tribunals to make orders for reference has a number of consequences. For example, it disincentivises referrals made under Article 267 TFEU, it affects the possibility of ensuring effective judicial remedies making use of EU law, it has the potential affect the uniformity and consistency in EU law, it slows litigation, and it ultimately hampers the mode of dialogue and communication between national courts and tribunals and the Court.

Appeals are still allowed, notwithstanding the increasing uselessness of such appeals being brought, given Cartesio eliminated some of the effects, and IS empower lower instance national courts and tribunals to invoke the primacy of EU law against national rules, and decisions of higher instance national courts and tribunal. Post-Cartesio and IS, however, how lower instance national courts and tribunals are to fully respond to appeals of orders for preliminary references is unclear, given they remain possible. The fact remains that the very climate of still allowing the appeals potentially lessens to effect that the preliminary reference procedure. In other words, there remain lingering questions about how far national law, national actors, and national courts, have a role in limiting the effects of orders for reference made under Article 267 TFEU.

In anything, the Court appears to be at pains to avoid a situation where it would rule that appeals against orders for reference are prohibited. This is demonstrated by its extremely incremental approach the Court has taken across both its 'old' and 'new' case law, whereby the Court has only come about these positions, as judges in lower instance national courts and tribunals, have, in essence, begged for judicial protection themselves. Admittedly, Cartesio pre-dated the emergence of subsequent rule of law and judicial independence issues in some of these Member States. IS, however, was in the midst of the litany of cases that Court has been dealing with for some years on the undermining of certain national judiciaries by certain Member States. Whilst the Court is creating a protected space for lower instance national courts and tribunals, more will continue to be asked of it generally, and specifically with regard the continued ability of lower instance national courts and tribunals to make orders for reference.

The Advocates General in two prior cases, in particular, were concerned about the wider chilling effects of appeals against decisions making preliminary references. AG Warner in Rheinmüblen Düsseldorf was of the view that failing to prohibit higher instance national courts and tribunals from interfering in dialogue between the Court and lower instance national courts and tribunals would be tantamount to enabling and seeing free qualification of the preliminary reference procedure, without having due regard to Article 267 TFEU. ${ }^{49}$ Given that in $I S$, the Court explicitly placed emphasis on the primacy of EU law - Article

\footnotetext{
49 Opinion of AG Warner in Rheinmüblen-Düsseldorf II and Rheinmüblen-Düsseldorf I (n 28).
} 
267 TFEU - over any national procedural measure, IS can be seen as a de facto endorsement of AG Warner's position, nearly half a century later. Secondly, AG Poiares Maduro in Cartesio feared that having appeals against orders for reference from lower instance national courts and tribunals would whittle down the procedure to only having courts of final instance referring. ${ }^{50}$ This fear did not come to pass, but with Cartesio, and now IS, it is likely that AG Poiares Maduro's worst fears will not now come to pass.

The EU legal order has moved on significantly since Cartesio, as demonstrated by the underlying facts of $I S$, in which a national judge was subject to disciplinary proceedings by making use of the preliminary reference procedure. Rightly, the Court took the opportunity to also state that such disciplinary proceedings. Beginning in the Association of Portuguese Judges case, ${ }^{51}$ the Court, in the face of persistent rule of law issues and the independence of national courts and tribunals in some Member States, commenced invoking stronger constitutional arguments on the nature of the EU legal order as basis for drawing the parameters of whom constitutes the European judiciary, and what the demands of it are. This rule of law case law has strengthened the demands of national judiciaries as a matter of EU law. ${ }^{52}$

Article 267 TFEU imposes, without question, the possibility for all national courts and tribunals to make orders for reference at their own motion, without any hindrance from higher instance national courts and tribunals. Yet, appeals are still conceivably possible. This requires clarity, and it can be pondered, if Cartesio and IS affirmatively eliminates the usefulness of bringing appeals against decision of lower instance national courts and tribunal to make orders for reference to higher instance national courts and tribunals, shouldn't the Court just state that appeals are not allowed?

The reasoning for this position in quite straightforward. National law, and higher instance national courts and tribunals, cannot reinterpret or amend Article 267 TFEU. The preliminary reference procedure therein is freestanding. Given Article 267 TFEU was not to be a reserve of higher instance national courts and tribunals, there ought to be next-to-no room for maneuver for higher instance national courts and tribunals to interfere with judicial dialogue taking place below them in lower instance national courts and tribunals. All national courts and tribunal, of whatever instance, have to have an unfettered and unfiltered possibility to interact with the Court through the preliminary reference procedure, given that Article 267 TFEU. At the next opportunity, the Court will be presented with a possibility to go further than it did in Cartesio and IS, and there should be no reason for the Court to be shy in prohibiting appeals of decisions of lower instance national courts and tribunals in their making of orders for references.

\section{CONCLUSION}

Lower instance national courts and tribunals must be aware that irrespective of the jurisprudence of higher instance national courts and tribunals, they have the right to engage

\footnotetext{
50 Opinion of AG Poiares Maduro in CARTESIO (n 41).

${ }^{51}$ Case C-64/16 Associação Sindical dos Juires Portugueses v Tribunal de Contas (Association of Portuguese Judges) ECLI:EU:C:2018:117.

${ }^{52}$ For comprehensive treatment of the post-Association of Portuguese Judges case law, see, Laurent Pech and Dimitry Kochenov, 'Respect for the Rule of Law in the Case Law of the European Court of Justice: A Casebook Overview of Key Judgments since the Portuguese Judges Case' (Swedish Institute for European Policy Studies 2021) 2021:3.
} 
in judicial dialogue with the Court through the preliminary reference procedure in Article 267 TFEU. The rights of all or all national courts and tribunals in EU Member States to make orders for reference to the Court is a matter governed by EU law, and not national law. It has long been the case, through the ages, that national measures which impede the functioning of the preliminary reference procedure 'must be set aside. ${ }^{53}$ Impeding judicial dialogue through the preliminary reference procedure - be it by national law, or by higher instance national courts and tribunals - only stands to interrupt formal means of judicial dialogue, and do damage to the very purpose of the procedure, which is to ensure uniform interpretation of EU law, and ensuring its consistent application throughout the Union.

There are ways of analysing the preliminary reference procedure through different theoretical lenses. ${ }^{54}$ It is a special procedure, given that it remains vastly different from other procedures before the Court, such as the numerous forms of direct actions. ${ }^{55}$ Yet it remains the predominant type of case which arrives on the Court's docket. Rightly, the Court has grown to more staunchly defend the preliminary reference procedure and the role of national courts in making such requests. ${ }^{56}$ But it will be forced to go further if lower instance national courts and tribunals decrease the number of cases referred when they ought to, or experience cold chilling effects in national legal orders if they are dissuaded from making orders for reference, owing to structural factors in Member States.

The case law, in this author's view, has to veer in the direction of not just being a mere tool in the hands of lower instance national courts and tribunals, but rather, one that is in their right under Article 267 TFEU, regardless of whatever higher instance national courts and tribunals think of such matters. Cartesio and $I S$ will not be the end of the dilemma. Respectfully, the Union is at a more advanced stage of constitutional integration, and the Court ought to be more affirmative than it has previously been to date.

There are numerous limitations imposed by EU law on national laws, rules, and practices, or any national measures interfering in the preliminary reference procedure. ${ }^{57}$ This now needs to go further. The permissive approach by the Court on the issue of appeals brought, whilst qualified in Cartesio and IS, has been a large demonstration of deference to national procedural rules. The Court may continue to underestimate the potential effects of such appeals against orders being permissible, deterring the willingness of lower instance national courts and tribunals to refer under Article 267 TFEU, and the dampening the enthusiasm of litigants to push for preliminary references to ensure the effectiveness of

\footnotetext{
${ }^{53}$ Eg, Case C-312/93 Peterbroeck, Van Campenhout \& Cie SCS v Belgian State ECLI:EU:C:1995:437, para 13. This, however, was established in Rheinmüblen Düsseldorf I (n 25).

${ }^{54}$ See, eg, John Cotter, Legal Certainty in the Preliminary Reference Procedure: The Role of Extra-Legal Steadying Factors (Edward Elgar Publishing 2022).

55 The most common direct action is the action for annulment, or nullity action, contained in Article 263 TFEU. See, on the distinction between the two, Angela Ward and Graham Butler, 'The Relationship between the Action for Annulment and Preliminary Reference Procedures: Opinion of Advocate General Jacobs in TWD' in Graham Butler and Adam Lazowski (eds), Shaping EU Law the British Way: UK Advocates General at the Court of Justice of the European Union (Hart Publishing 2022).

${ }^{56}$ For a recent reassertion, see Joined Cases C-558/18 and C-563/18 Miasto Lowicz and Prokurator Generalny zastepowany przez. Prokurature Krajowa formerly Prokuratura Okregowa w Ptocku v Skarb Państwa - Wojewoda Lódzki and Others ECLI:EU:C:2020:234, paras 55-59 and cited case law therein.

${ }^{57}$ See, eg, Rosario Silva de Lapuerta, 'The Right of Any Court or Tribunal of a Member State to Request a Preliminary Ruling from the Court of Justice of the European Union' in Koen Lenaerts and others (eds), Building the European Union: The Jurist's View of the Union's Evolution: Liber Amicorum in Honour of José Luis da Cruz. Vilaça (Hart Publishing 2021).
} 
Union law. There are undoubtedly blind spots in the preliminary reference procedure. ${ }^{58}$ But with more assertive lower instance national courts and tribunals highlighting issues, the Court cannot be naïve about what is taking place in EU Member States.

${ }^{58}$ On prior musings, when the preliminary reference procedure is gainfully used in a fraudulent manner, see Graham Butler and Urška Šadl, 'The Preliminaries of a Reference' (2018) 43 European Law Review 120. 


\section{LIST OF REFERENCES}

Arnull A, 'The Past and Future of the Preliminary Rulings Procedure' in Mads Andenas and John A Usher (eds), The Treaty of Nice and Beyond: Enlargement and Constitutional Reform (Hart Publishing 2003).

DOI: https://doi.org/10.5040/9781472562852.ch-013

Bobek M, 'Cartesio: Appeals against an Order to Refer under Article 234(2) EC Treaty Revisited' (2010) 29 Civil Justice Quarterly 307.

Broberg M and Fenger N, 'Preliminary References as a Right - but for Whom? The Extent to Which Preliminary Reference Decisions Can Be Subject to Appeal' (2011) 36 European Law Review 276.

—, Broberg and Fenger on Preliminary References to the European Court of Justice (Third Edition, Oxford University Press 2021).

DOI: https://doi.org/10.1093/oso/9780198843580.001.0001

Butler G and Cotter J, 'Just Say No! Appeals Against Orders for a Preliminary Reference' (2020) 26 European Public Law 615.

Butler G and Lazowski A (eds), Shaping EU Law the British Way: UK Advocates General at the Court of Justice of the European Union (Hart Publishing 2022).

Butler G and Šadl U, ‘The Preliminaries of a Reference’ (2018) 43 European Law Review 120.

Cotter J, Legal Certainty in the Preliminary Reference Procedure: The Role of Extra-Legal Steadying Factors (Edward Elgar Publishing 2022).

Groussot X, 'Spirit Are You There? - Reinforced Judicial Dialogue and the Preliminary Ruling Procedure' (2008) Europarättslig tidskrift 934.

DOI: https://doi.org/10.2139/ssrn.1279367

Jacobs FG and Durand A, References to the European Court: Practice and Procedure (Butterworths 1975).

Keeling DT, 'The Rehabilitation of Trade Marks, the Demise of the Doctrine of Common Origin, and the Overruling of Prior Case Law: Opinion of Advocate General Jacobs' in HAG II' in Graham Butler and Adam Lazowski (eds), Shaping EU Law the British Way: UK Advocates General at the Court of Justice of the European Union (Hart Publishing 2022).

Kuisma M, 'Confronting Realities with the Legal Rule: On Why and How the European Court of Justice Changes Its Mind' (University of Turku 2021). 
Lacchi C, 'Multilevel Judicial Protection in the EU and Preliminary References' (2016) 53 Common Market Law Review 679.

Lenaerts K, 'Form and Substance of the Preliminary Rulings Procedure' in Deirdre Curtin and Tom Heukels (eds), Institutional Dynamics of European Integration: Essays in Honour of Henry G. Schermers, Volume II (Martinus Nijhoff Publishers 1994).

Murphy F, 'Campus Oil Ltd., Estuary Fuel Ltd., McMullan Bros. Ltd, Ola Teoranta, P.M.P.A. Oil Company Ltd., Tedcastle McCormick and Company Ltd. v. The Minister for Industry and Energy, Ireland, The Attorney General and The Irish National Petroleum Corporation Ltd. (1982-1983) J.I.S.E.L. 43; (1984) 1 C.M.L.R. 479.' (1984) 21 Common Market Law Review 741.

O'Keeffe D, 'Appeals Against an Order to Refer under Article 177 of the EEC Treaty' (1984) 9 European Law Review 87.

Pech L and Kochenov D, 'Respect for the Rule of Law in the Case Law of the European Court of Justice A Casebook Overview of Key Judgments since the Portuguese Judges Case' (Swedish Institute for European Policy Studies (SIEPS) 2021) 2021:3.

Rosas A, 'The Preliminary Rulings Procedure' in Dennis Patterson and Anna Södersten (eds), A Companion to European Union Law and International Law (John Wiley \& Sons, Inc 2016).

Silva de Lapuerta R, 'The Right of Any Court or Tribunal of a Member State to Request a Preliminary Ruling from the Court of Justice of the European Union' in Koen Lenaerts and others (eds), Building the European Union: The Jurist's View of the Union's Evolution: Liber Amicorum in Honour of José Luis da Cruz Vilaça (Hart Publishing 2021).

Ward A and Butler G, 'The Relationship between the Action for Annulment and Preliminary Reference Procedures: Opinion of Advocate General Jacobs in TWD' in Graham Butler and Adam Lazowski (eds), Shaping EU Law the British Way: UK Advocates General at the Court of Justice of the European Union (Hart Publishing 2022). 